\title{
Highly sensitive and rapid gene mapping using miniaturized blot hybridization: application to prenatal diagnosis
}

(Rapid amniocyte DNA extraction; mini-gel electrophoresis; mapping sickle cell genes; fetal genotype; restriction analysis)

\section{David J. Law, Philippe M. Frossard and Donald L. Rucknagel}

Department of Human Genetics, University of Michigan Medical School, Ann Arbor, MI 48109 (U.S.A.) Tel. (313) 763-2536

(Received October 19th, 1983)

(Revision received December 29th, 1983)

(Accepted December 30th, 1983)

\section{SUMMARY}

We have developed a protocol for the preparation and analysis of amniocyte DNA which permits more sensitive and more rapid antenatal detection of sickle-cell anemia (SCA) than previously has been possible. After rapid extraction of DNA from amniotic cells, only $50 \mathrm{ng}$ of $\mathrm{Mst} \mathrm{Il}$-digested DNA need be analyzed by mini-gel electrophoresis and hybridization detection to determine reliably the fetal genotype. Under these conditions, the entire gene-mapping procedure can be performed within 5 days. When larger amounts of DNA $(>500 \mathrm{ng}$ ) are analyzed, the minimal diagnosis time is reduced to 2 days. The resolution of restriction fragments on mini-gels is comparable to that obtained with larger gels. The $1.15-\mathrm{kb} \beta^{\wedge}$ and $1.35-\mathrm{kb} \beta^{\mathrm{S}}$ Mst II fragments are well separated. The technique is useful whenever rapid and sensitive analysis of genomic DNA is desired.

\section{INTRODUCTION}

Techniques for the prenatal diagnosis of SCA by restriction endonuclease analysis of amniocyte DNA have improved recently. In earlier gene-mapping studies segregation analysis of polymorphic restriction sites linked to the $\boldsymbol{\beta}^{\mathbf{S}}$ mutation allowed prenatal diagnosis in up to $86 \%$ of the pregnancies at risk for SCA (Kan and Dozy, 1978a,b; Phillips et al., 1980;

Abbreviations: $A A, A S, \beta$-globin genotypes (see MATERIALS AND METHODS, section a); $\beta^{\mathbf{A}}$, normal $\beta$-globin allele; $\beta^{\mathbf{S}}$, sickle $\beta$-globin allele; $E$ buffer, $36 \mathrm{mM}$ Tris base, $30 \mathrm{mM}$ $\mathrm{NaH}_{2} \mathrm{PO}_{4}, 1$ mM EDTA, pH 7.8; EtBr, ethidium bromide; $\mathbf{k b}$, kilobase pairs; SCA, sickle-cell anemia; SSC, $150 \mathrm{mM} \mathrm{NaCl}$, $15 \mathrm{mM} \mathrm{Na}$. citrate, pH 7.6; SDS, sodium dodecyl sulfate; SSPE, $180 \mathrm{mM} \mathrm{NaCl}, 10 \mathrm{mM} \mathrm{NaH} \mathrm{PO}_{4}, 1 \mathrm{mM}$ EDTA, pH 7.4.
Boehm et a!., 1983). Later, direct analysis of the $\beta^{\text {S }}$ allele became possible with the discovery of the restriction enzyme DdeI (Makula and Meagher, 1980), whose recognition sequence (CTNAG) is present in codons 5 and 6 of normal DNA, but is lost in $\beta^{\text {S }}$ DNA (Geever et al., 1981). However, the relatively small $D$ del $\beta^{\mathrm{A}}$ and $\beta^{\mathrm{S}}$ fragments required the digestion of 10-20 $\mu$ g of genomic DNA (Char: and Kan, 1981; Geever et al., 1981; Wilson et al., 1982).

Prenatal diagnosis of SCA can be performed with greater sensitivity by employing the restriction endonuclease $M$ st II, which also differentiates $\beta^{\mathrm{A}}$ and $\beta^{\mathrm{S}}$ alleles (Chang and Kan, 1982; Chang et al., 1982; Orkin et al., 1982; Wilson et al., 1982). Since the Mst II recognition sequence occurs less frequently than does the DdeI sequence, using conventional 
gene mapping procedures, as little as $1 \mu \mathrm{g}$ of genomic DNA can be analyzed within about 2 weeks (Chang and Kan, 198E).

We have improved both the sensitivity and efficiency of the Mst II prenatal assay for SCA. A rapid DNA extraction procedure, combined with mini-gel electrophoretic analysis of MstII fragments permits unambiguous diagnosis with as little as $\mathbf{5 0} \mathrm{ng}$ of genomic DNA. Depending upon the amount of DNA analyzed, the entire procedure can be completed within 2-5 days. The procedures we describe are generally useful for rapid and sensitive analysis of genomic DNA.

\section{MATERIALS AND METHODS}

\section{(a) Rapid DNA extraction}

The cells contained in 5-20 ml of amniotic fluid obtained at 16-18 weeks gestational age are pelleted ai $12000 \times g$ (10000 rev./min, Sorvall SS-34 rotor) at $4^{\circ} \mathrm{C}$ for $5 \mathrm{~min}$, washed twice with $5 \mathrm{ml}$ of $0.9 \%$ $\mathrm{NaCl}$, and resuspended in $400 \mu \mathrm{l}$ of lysis buffer $(20 \mathrm{mM}$ Tris $\cdot \mathrm{HCl}, 0.3 \mathrm{M}$ sodium acetate, $1 \mathrm{mM}$ EDTA, pH 7.5) in a 1.5-ml eppendorf tube. Proteinase $K$ is added to $150 \mu \mathrm{g} / \mathrm{ml}$, and SDS is added to
$0.2 \%$. Complete lysis occurs within $1-6 \mathrm{~h}$ incubation at $37^{\circ} \mathrm{C}$.

The lysates are extracted three times (6 min each) with phenol-chloroform $(1: 1)$, and three times (6 min each) with an equal volume of anhydrous ethyl ether. The aqueous and organic phases are separated by centrifugation for $3 \mathrm{~min}$ in a Beckman microfuge. Nucleic acids are precipitated by the addition of 2.5 vols. of cold $\left(-20^{\circ} \mathrm{C}\right)$ ethanol, and by incubation for $20 \mathrm{~min}$ at $-80^{\circ} \mathrm{C}$. To estimate DNA concentration, a sample is electrophoresed on a minigel with known amounts of undigested $\lambda$ DNA. The rapid extraction procedure can be used with minor modifications for extraction of DNA from tissues and from peripheral blood buffy coats. Control human genomic DNAs with known $\beta$-globin genotypes $(A A, A S, S S)$ were extracted as described previously (Bruzdzinski et al., 1983).

\section{(b) Isolation and labeling of the human 5 '- $\beta$-globin probe}

The probe used for this study is the 1.15-kb Mst II fragment which extends from the Mst II site at codons 5-7 of the normal human $\beta$-globin gene $\left(\beta^{A}\right)$ to the closest MstII site in the $5^{\prime}$-flanking region (Fig. 1). We purified this fragment from plasmid
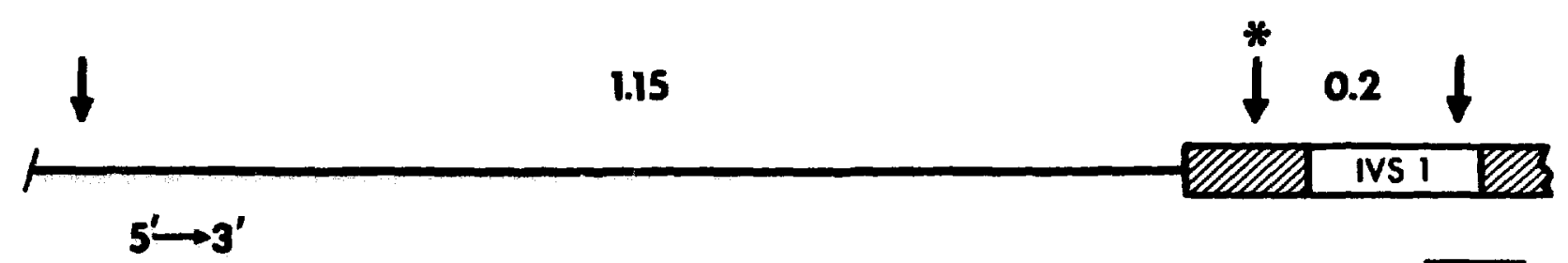

$\overline{100 b p}$

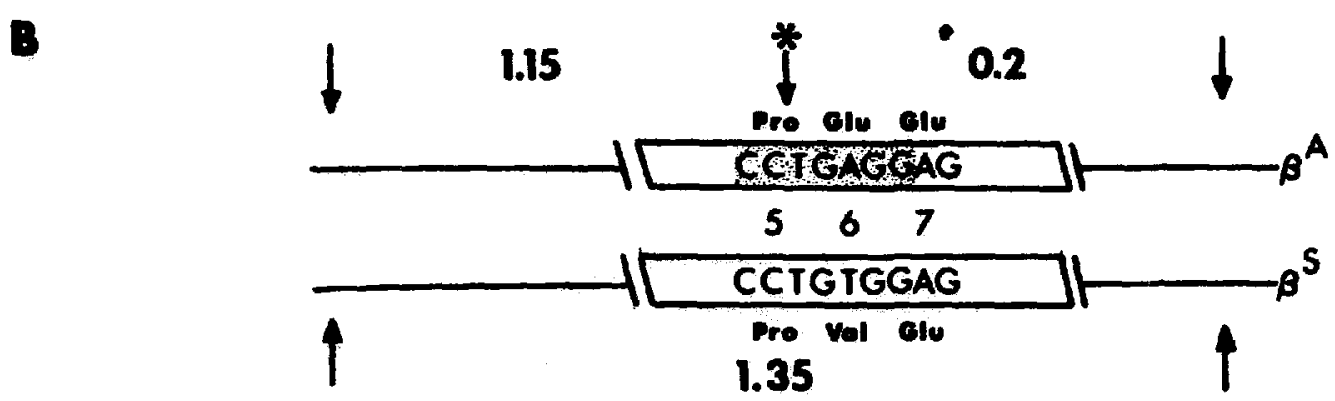

Fig. 1. Mst II restriction map of human $\beta$-globin genes. (A) Mst II șites ( $\downarrow$ ) in the 5 -flanking (heavy line) and coding (hatched box) regions of the normal $\left(\beta^{\wedge}\right)$ gene. Fragment sizes (kb) and scale are indicated; IVS, intervening sequence. (B) Enlarged diagram (not to scale) of the sequences at codons $5-7$ in the normal and sickle $\left(\beta^{5}\right)$ alleles. Stipled area, Mst II recognition sequence; asterisk indicates $M s t$ II site present in normal but absent in sickle gene. 
H $\beta 1$ S (Lawn et al., 1978), filled its termini with Klenow fragment of DNA polymerase I (BRL), and subcloned it into the Smal site of plasmid pUC-8 (Messing and Vieira, 1982). Either the entire subclone ( $\mathrm{pH} \beta 1.15 \mathrm{M}$ ) or the gel-purified 1.15-kb insert is labeled with $\left[\alpha-{ }^{32} \mathrm{P}\right] \mathrm{dCTP}$ (Amersham, 400 $\mathrm{Ci} / \mathrm{mmol}$ ) by nick translation (Rigby et al., 1979) using a kit supplied by BRL. Specific activities $\geq 5 \times 10^{7} \mathrm{cpm} / \mu \mathrm{g}$ are suitable for detection.

\section{(c) Sample preparation and mini-gel electrophoresis}

DNA is digested with Mst II (New England Biolabs) under conditions recommended by the supplier for $\geq 3 \mathrm{~h}$. Digested DNA samples are electrophoresed in horizontal, $6 \times 10 \times 0.5 \mathrm{~cm}, 1.4 \%$ agarose gels in $\mathrm{E}$ buffer, at $60 \mathrm{~V}$ for 2-3 $\mathrm{h}$ with buffer recirculation and cooling.

(d) DNA transfer, hybridization, and detection procedures

DNA fragments are denatured for $10 \mathrm{~min}$ in two changes of $0.5 \mathrm{~N} \mathrm{NaOH}, 1.5 \mathrm{M} \mathrm{NaCl}$, and neutralized by soaking $2 \times 5 \mathrm{~min}$ in $1 \mathrm{M}$ ammonium acetate, pH 7.0. The fragments are blotted (Southern, 1975) onto nitrocellulose $(0.45 \mu \mathrm{m}$, Schleicher and Schuell, Inc.) in $20 \times \mathrm{SSC}$ for $\geq 2 \mathrm{~h}$ at room temperature and are fixed to the filters for $2 \mathrm{~h}$ at $80^{\circ} \mathrm{C}$ in vacuo. Filters are prehybridized for $2-4 \mathrm{~h}$ at $42^{\circ} \mathrm{C}$ in plastic bags containing $5 \times$ SSPE, $35 \%$ formamide (MCB), $5 \times$ Denhardt's solution $(5 \times=0.1 \%$ bovine serum albumin, $0.1 \%$ Ficoll, $0.1 \%$ polyvinyl polypyrrolidone), and $250 \mu \mathrm{g} / \mathrm{ml}$ of sheared, denatured salmon sperm DNA, using $0.5 \mathrm{ml}$ of solution per $\mathrm{cm}^{2}$ filter area. Hybridization is perfermed for $\geq$ $10 \mathrm{~h}$ at $42^{\circ} \mathrm{C}$ in $5 \times$ SSPE, $35 \%$ formamide, $1 \times$ Denhardt's solution, $10 \%$ dextran sulfate, $100 \mu \mathrm{g} / \mathrm{ml}$ denatured salmon sperm DNA, and $100 \mathrm{ng}$ of the nick-translated 1.15-kb Mst II fragment (see above and Fig. 1), using $0.2 \mathrm{ml}$ of solution per $\mathrm{cm}^{2}$ filter area.

Filters are washed for $2 \times 10 \mathrm{~min}$ at room temperature in $2 \times \mathrm{SSC}, 0.1 \% \mathrm{SDS}$, and for $2 \times 20 \mathrm{~min}$ at $65^{\circ} \mathrm{C}$ in $2 \times \mathrm{SSC}, 1 \times$ Denhardt's solution, $0.1 \%$ SDS. Autoradiography is performed with XAR-5 film (Kodak) and Cromex intensifying screens (Dupont) at $-80^{\circ} \mathrm{C}$ for appropriate intervals (Table I).
TABLE I

Improved efficiency and sensitivity in gene-mapping procedures

\begin{tabular}{ll}
\hline Procedure & $\begin{array}{l}\text { Minimum time } \\
\text { required }(\mathrm{h})\end{array}$ \\
\hline
\end{tabular}

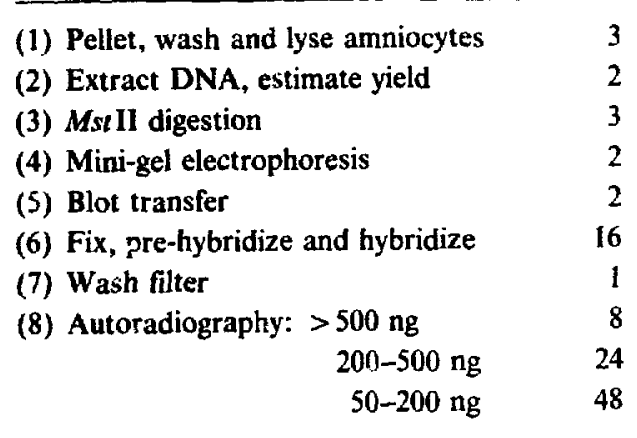

\section{RESULTS}

(a) Rapid extraction of DNA from amniotic cells

With a goal to improve the rapidity and sensitivity of the prenatal Mst II assay for SCA, we developed a more rapid amniocyte DNA extraction procedure. Previously, when washed amniocytes were resuspended in a lysis buffer containing SDS, clumps of cells formed and these required prolonged incubation to be dispersed and lysed. In the present procedure, cells are uniformly suspended before lysis is initiated by the addition of proteinase $\mathrm{K}$ and SDS, resulting in complete lysis within $2 \mathrm{~h}$. The small lysate volume $(0.4 \mathrm{ml})$ permits rapid DNA extraction in eppendorf tubes so that nucleic acids can be extracted and the DNA yield can be estimated within $2 \mathrm{~h}$. Although significant RNA contamination is evident on a stained gel, this material in no way interferes with restriction enzyme digestion, or with blotting and detection procedures. Control DNAs, extracted from peripheral blood samples by a conventional procedure (Bruzdzinski et al., 1983), and amniocyte DNA, extracted by the rapid procedure, are indistinguishable in their suitability for gene mapping (see Fig. 2). DNA yields also are unaffected by the rapid lysis and extraction procedures. 
(b) Resolution of Mst II $\boldsymbol{\beta}$-globin gene fragments on mini-gels

In an attempt 'o further improve the efficiency and sensitivity of SCA prenatal diagnosis, we tested the usefulness of mini-gel electrophoresis. Our first concern was that the mini-g:ls provide sufficient resolution to clearly distinguish a $1.15-\mathbf{k b} \beta^{\mathrm{A}}$ fragment from a 1.35-kb $\beta^{\mathrm{s}}$ fragmert. When 300-500-ng samples of Mst II-digested DNA are electrophoresed for $2 \mathrm{~h}$ in a $1.4 \%$ agarose gel, hj bridization analysis shows that the 1.15 - and $1.35-\mathrm{kb}$ bands are clearly separated (Fig. 2).

Fig. 2 also shows that use of the 1.15-kb Mst II $\beta^{A}$ fragment as a hybridization probe reduces the number of cross-hybridizing fragments and results in more uniform hybridization intensity with the $\beta^{A}$ and $\boldsymbol{\beta}^{\mathbf{S}}$ fragments than when larger $\boldsymbol{\beta}$-globin probes are used (Chang and Kan, 1982; Orkin et al., 1982).

(c) Increased sensitivity of hybridization detection with the mini-gel format

When using standard-sized gels, the limit of detection for a single-copy gene fragment in human genomic DNA is on the order of 1-2 $\mu \mathrm{g}$. As seen in Fig. 3 , the use of mini-gels in the MstII assay for SCA, permits the detection of the $\beta^{\mathbf{A}}$ and $\beta^{\mathbf{S}}$ fragments within $200 \mathrm{ng}$ of $A S$ genomic DNA in an overnight exposure. With increased exposure time ( $\geq 2$ days) sensitivity is increased further to $50 \mathrm{ng}$.
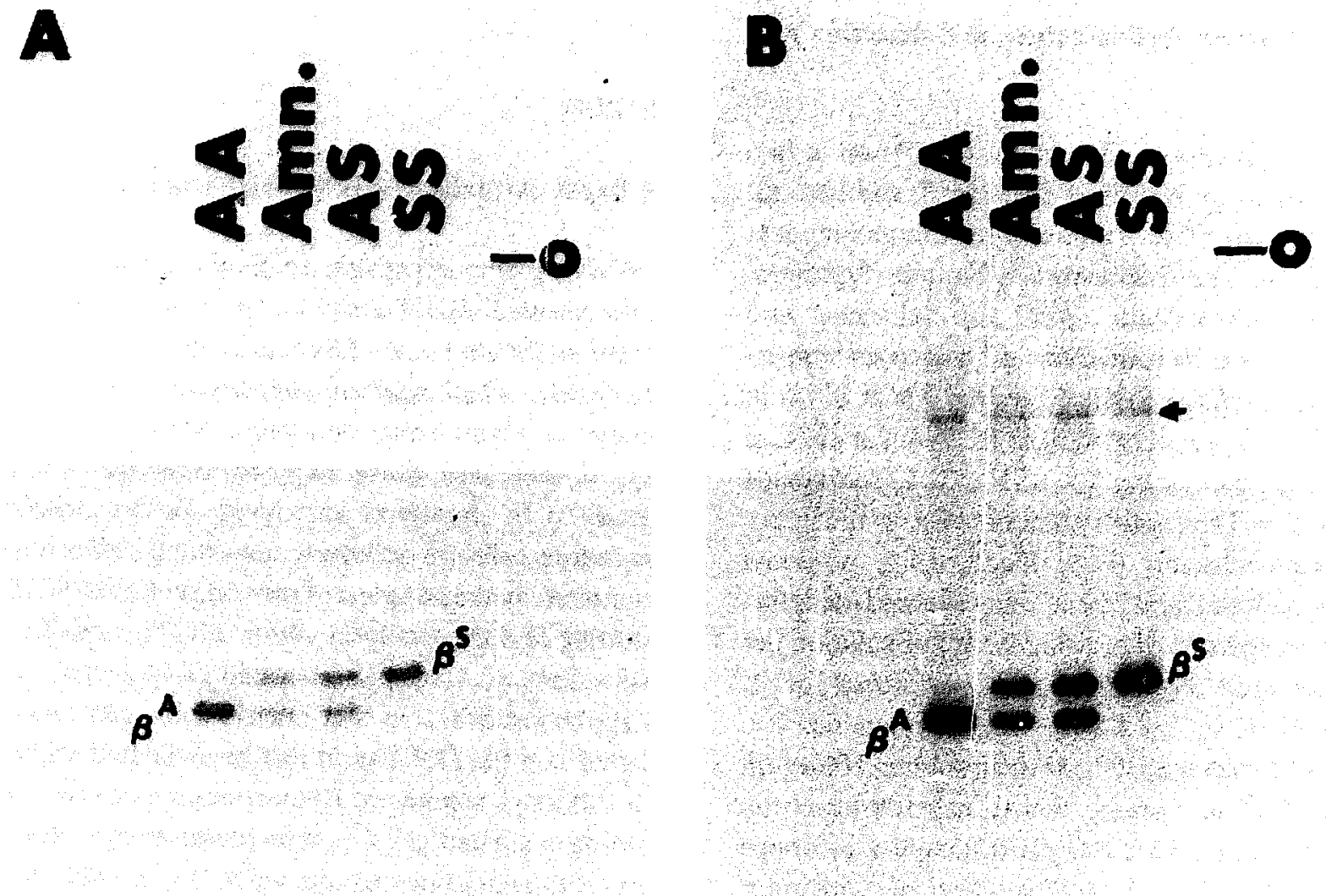

Fig. 2. Resolution of $M s t$ II $\beta^{A}(1.15 \mathrm{~kb})$ and $\beta^{s}(1.35 \mathrm{~kb})$ fragments by mini-gel electrophoresis and hybridization dettction. $500 \mathrm{ng}$ samples of control DNAs $(A A, A S, S S)$ and a $300 \mathrm{ng}$ sample of amniocyte DNA (Amn.) were digested with Mst II, electrophoresed in a $1.4 \%$ agarose mini-gel, and transferred and hybridized with $100 \mathrm{ng}$ of the nick-translated $1.15-\mathrm{kb}, \beta^{A}, M s t$ II fragment (5 $\left.\times 10^{7} \mathrm{cpm} / \mu \mathrm{g}\right)$ as described in MATERIALS AND METHODS, sections h-d. (A) 12-h autoradiogram; (B) 60-h autoradiogram. A fainter, 6-kb, cross hybridizing $\delta$-globin gene fragment also is detected (arrow). 0 , origin. 
A
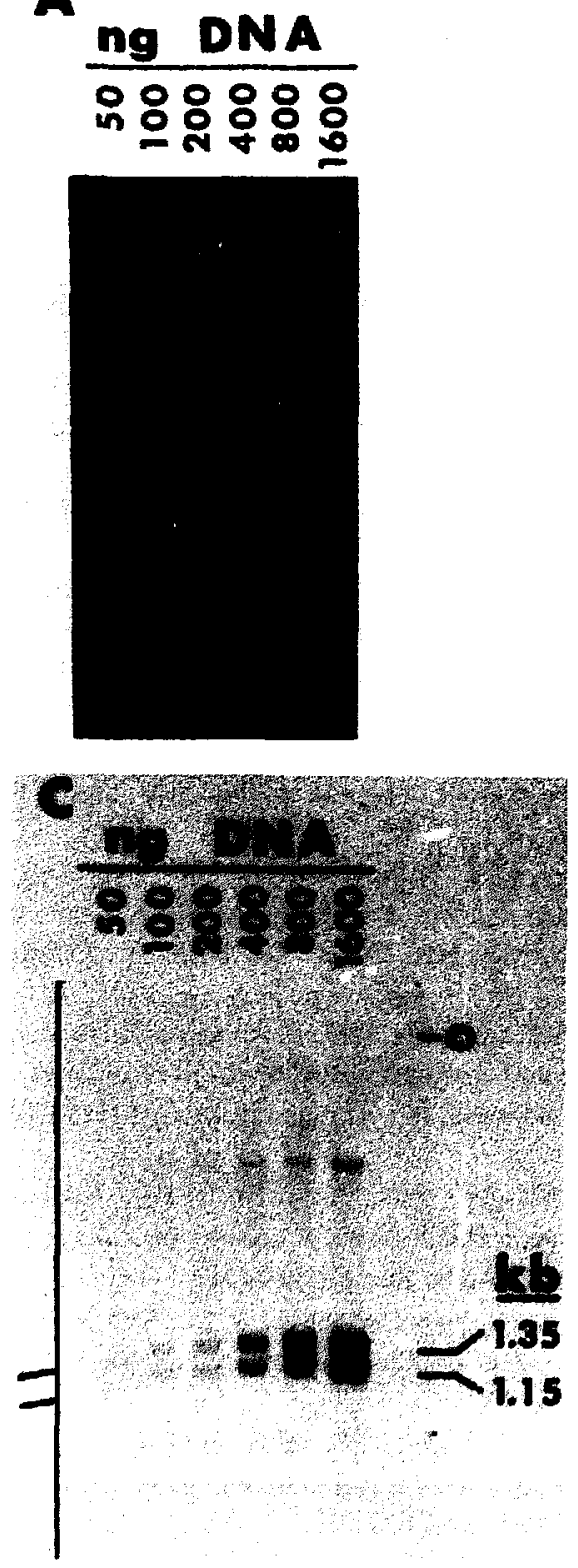

B
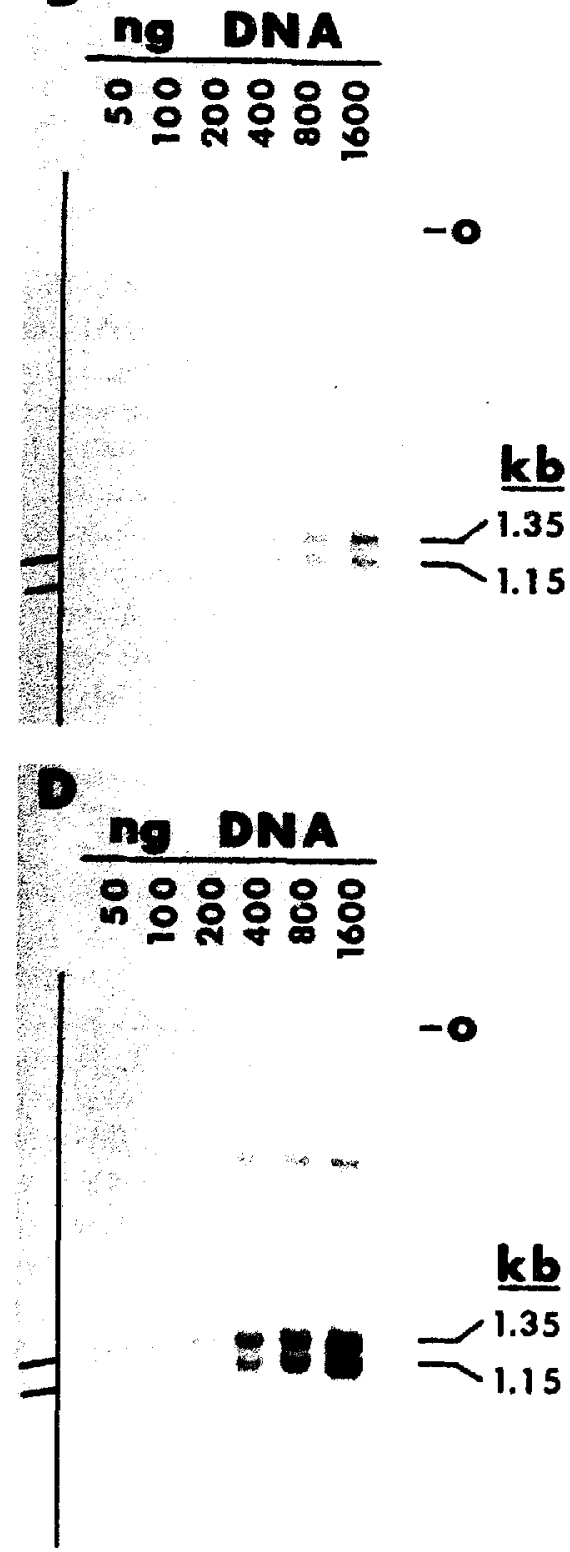

Fig. 3. Sensitivity of mapping single-copy gene fragments in DNA from a heterozygote. (A) Photograph of an EtBr-stained mini-gel containing MstIl-digested genomic $A S$ DNA in the amounts indicated. (B-D) 16-h, 2.5-day, and 5-day autoradiograms, respectively, of the transferred and hybridized $\beta^{A}(1.15-\mathrm{kb})$ and $\beta^{\mathrm{s}}(1.35-\mathrm{kb})$ fragments.

\section{DISCUSSION}

Previously, antenatal detection of SCA by Mst II mapping of the $\beta^{A}$ and $\beta^{S}$ alleles has required the analysis of at least $1 \mu \mathrm{g}$ of fetal DNA over a period of about 2 weeks (Chang and Kan, 1982; Chang et al., 1982; Orkin et al., 1982; Wilson et al., 1982). With the DNA-extraction and mini-gel procedures we have developed, as little as $50 \mathrm{ng}$ of genomic
DNA can be analyzed to provide a reliable diagnosis within 5 days. When larger amounts of DNA are analyzed ( $\geq 200 \mathrm{ng}$ ) diagnosis time can be reduced to 2-3 days (Table I). In addition to shortening diagnosis time, the increased sensitivity of the mini-ge! assay permits diagnosis with less amniotic fluid. Thus far, we have isolated ample DNA from the cells contained in as little as $5 \mathrm{ml}$ of amniotic fluid obtained at about 16 weeks gestational age. The volume 
and the gestational age limits for the efficient recovery of DNA from amniotic fluid are still being investigated.

The increased sensitivity provided by mini-gel analysis does not involve significant loss of resolution. Under the conditions described, the resolution of DNA remains comparable to that obtained with larger gels. Together, these improvements offer several advantages: (1) antenatal detection at earlier gestational ages and/or with less amniotic fluid; (2) ability to perform several assays on the same DNA sample should the need arise; (3) no need to culture amniotic cells; and (4) conservation of enzymes and reagents.

These DNA extraction and mini-gel analysis procedures are generally useful for mapping gene fragments in genomic DNA, particularly when speed and sensitivity are desired. In addition to amniotic cells, we have used the rapid extraction procedure with minor modifications to prepare DNA from human peripheral blood buffy coats, from human fetal liver, and from whole mice. Apart from the Mst II assay for SCA, we have applied these techniques to: (1) mapping $\beta^{A}$ and $\beta^{S}$ alleles with DdeI; (2) mapping the $\beta^{\text {D Punjab }}$ allele with EcoRI; (3) mapping the $\beta^{E}$ allele with $H p h I$; and (4) screening large numbers of DNA samples for restriction fragment length polymorphisms.

\section{ACKNOWLEDGEMENTS}

Portions of this research were supported by grants from the National Foundation March of Dimes and the National Institutes of Health (RO1-AM-20964). D. Law is a National Research Service Award Trainee (GM-07123-08). We thank Dr. Tom Maniatis for generously providing plasmid H $\beta$ IS, Carolyn J. Bruzdzinski and Steven J. Ferrucci for technical assistance, and Mary Kellogg for invaluable clerical assistance.

\section{REFERENCES}

Boehm, C.D., Antonarakis, S.E., Phillips, J.A. III, Stetten, G. and Kazazian Jr., H.H.: Prenatal diagnosis using DNA poly- morphisms: report on 95 pregnancies at risk for sickle cell disease or $\beta$-thalassemia. N. Engl. J. Med. 308 (1983) 1054-1058.

Bruzdzinski, C.J., Sisco, K.L., Ferrucci, S.J. and Rucknagel, D.L.: The occurrence of the $\alpha^{\text {G.Philadetphia }}$ globin allele on a double locus chromosome. Am. J. Hum. Genet. 36 (1984) 101-109.

Chang, J.C., Golbus, M.S. and Kan, Y.W.: Antenatal diagnosis of sickle cell anaemia by sensitive DNA assay. Lancet ii (1982) 1463.

Chang, J.C. and Kan, Y.W.: Antenatal diagnosis of sickle cell anaemia by direct analysis of the sickle mutation. Lancet ii (1981) 1127-1129.

Chang, J.C. and Kan, Y.W.: A sensitive new prenatal test for sickle-cell anemia. N. Engl. J. Med. 307 (1982) 30-32.

Geever, R.F., Wilson, L.B., Nallaseth, F.S., Milner, P.F., Bittner, M. and Wilson, J.T.: Direct idertification of sickle cell aneria by blot hybridization. Proc. Natl. Acad. Sci. USA 78 (1981) 5081-5085.

Kan, Y.W. and Dozy, A.M.: Antenatal diagnosis of sickle-cell anaemia by DNA analysis of amniocyte-fluid cells. Lancet ii (1978a) 910-912.

Kan, Y.W. and Dozy, A.M.: Polymorphisms of DNA sequence adjacent to human $\beta$-globin structural gene: relationship to sickle mutation. Proc. Natl. Acad. Sci. USA 75 (1978b) 5631-5635.

Lawn, R.M., Fritsch, E.F., Parker, R.C., Blake, G. and Maniatis, T.: The isolation and characterization of linked S- and $\beta$-globin genes from a cloned library of human DNA. Cell 15 (1978) 1157-1174.

Makula, R.A. and Meagher, R.B.: A new restriction endonuclease from the anaerobic bacterium, Desulfovibrio desulfuricans, Norway. Nucl. Acids Res. 8 (1980) 3125-3131.

Messing, J. and Vieira, J.: A new pair of M13 vectors for selecting either DNA strand of double-digest restriction fragments. Gene 19 (1982) 269-276.

Orkin, S.H., Little, P.F.R, Kazazian Jr., H.H. and Boehm, C.D.: Improved detection of the sickle mutation by DNA analysis. N. Engl. J. Med. 307 (1982) 32-36.

Phillips, J.A., III, Panny, S.R., Kazazian Jr., H.H., Boehm, C.D., Scott, A.F. and Smith, K.D.: Prenatal diagnosis of sickle cell anaemia by restriction endonuclease analysis: HindIII polymorphisms in $\gamma$-globin genes extend test applicability. Proc. Natl. Acad. Sci. USA 77 (1980) 2853-2856.

Rigby, P.WJ., Dieckman, M., Rhodes, C. and Berg, P.: Labeling deoxyribonucleic acid to high specific activity by nick translation with DNA polymerase 1. J. Mol. Biol. 113 (1977) 237-251.

Southern, E.M.: Detection of specific sequences among DNA fragments separated by gel electrophoresis. J. Mol. Biol. 98 (1975) 503-517.

Wilson, J.T., Milner, P.F., Summer, M.E., Nallaseth, F.S., Fadel, H.E., Reindollar, R.H., McDonough, P.G. and Wison, L.B.: Use of restriction endonucleases for mapping the allele for $\beta^{5}$-globin. Proc. Natl. Acad. Sci. USA 79 (1982) 3628-3631.

Communicated by A.I. Bukhari. 